\title{
Testing Fisher Hypothesis in long horizons for G7 and several Asian
}

\author{
countries
}

\author{
Ka-fu Wong* \\ and \\ Hai-jun $\mathrm{Wu}$ \\ Chinese University of Hong Kong
}

October 5, 2001

\begin{abstract}
Using monthly data from G7 and eight Asian countries, we find support for Fisher Hypothesis, as well as a positive relation between long-horizon nominal stock returns and expected inflation but not between long-horizon nominal stock returns and contemporaneous inflation. Our empirical results complement and strenghten those of Boudoukh and Richardson (1993).
\end{abstract}

Keywords: Fisher Hypothesis, long-horizon regression, stock returns, inflation.

JEL classification: G0, E0

\section{Introduction}

Fisher Hypothesis is an important hypothesis in Economics and Finance and has often been used as an assumption in or derived as a side implication from theoretical models. The hypothesis

\footnotetext{
${ }^{*}$ Ka-fu Wong gratefully acknowledges financial support from the Chinese University of Hong Kong. Please send all correspondence to: Ka-fu Wong, Department of Economics, Chinese University of Hong Kong, Shatin, Hong Kong, China. Email: kafuwong@cuhk.edu.hk; tel: (852) 2609-7050; fax: (852) 2603-5805. The MATLAB program and data to compute the results in this paper is available from http://kafuwong.econ.cuhk.edu.hk/research/fisher/.
} 
postulates that nominal rate of stock returns reflects the market expectation about the real rate of stock returns and inflation rate; that is, one percentage increase in expected inflation should be associated with one percentage increase in nominal stock returns. The Fisher Hypothesis implies that investment in stocks may be used to hedge against inflation completely. Furthermore, the coefficient estimate from a regression of nominal stock returns on expected inflation should be close to unity statistically.

$$
R_{t, k}=\alpha+\beta E\left(\pi_{t, k} \mid I_{t-k}\right)+\epsilon_{t, k}
$$

where $R_{t, k}$ and $\pi_{t, k}$ are respectively the nominal stock returns and inflation rate from time $t-k$ to $t ; \alpha$ is the expected real rate of stock returns; $\beta$ equals one under Fisher Hypothesis; $E\left(\pi_{t, k} \mid I_{t-k}\right)$ is the expectation of inflation from period $t-k$ to $t\left(\pi_{t, k}\right)$ based on the information set $I_{t-k}$ available at $t-k$; and $\epsilon_{t, k}$ is the residual.

Because expectation of inflation is not available in general, the estimation of the coefficients has to rely on a regression model of observables:

$$
R_{t, k}=\alpha+\beta \pi_{t, k}+u_{t, k}
$$

Note that the residual is now $u_{t, k}$ instead of $\epsilon_{t, k}$. By simple calculation, we can see that $u_{t, k} \equiv$ $\epsilon_{t, k}+\beta\left[E\left(\pi_{t, k} \mid I_{t-k}\right)-\pi_{t, k}\right]$ is correlated with $\pi_{t, k}$. Consequently, an ordinary least squares (OLS) estimation will yield inconsistent estimates of the coefficients. However, if we have a variable that is correlated with $\pi_{t, k}$ but uncorrelated with $u_{t, k}$, we may estimate the coefficient consistently using instrumental variables (IV) or generalized method of moments (GMM) estimation. Such variables, known as instrumental variables, are readily available because all information in $I_{t-k}$ are uncorrelated with $u_{t, k}$ and some information in $I_{t-k}$ (such as $\pi_{t-k, k}$ ) are known to be correlated with $\pi_{t, k}$. For a description of the estimation methods of instrumental variables and generalized method of moments, please refer to Campbell, Lo and MacKinlay (1997, Appendix 1).

Strictly speaking, Fisher Hypothesis should hold at all horizons. However, based on shorthorizon data, most previous empirical studies found a negative relation - a miserable failure. 
Examples include Fama (1975), Bodie (1976), Nelson (1976) and Fama and Schwert (1977).

Recently, Boudoukh and Richardson (1993) re-investigated the relation using annual United States and the United Kingdom data and found that long-horizon (five years) nominal stock returns are postively related to both ex ante (instrumental variables estimation) and ex post (ordinary least squares) long-term inflation. However, there is no evidence from other countries and data sets.

In this paper, we test the Fisher Hypothesis at short- and long-horizon using data from fifteen countries, including G7 and eight Asian countries.

\section{Data}

We use monthly data because long annual time series are often not available for most countries, except for the United States and United Kingdom. Monthly consumer price indices (CPIs) and stock indices (SIs) are drawn mainly from the International Financial Statistics and the Datastream database. The data appendix describes in details the sources of data and their series codes. Inflation rates and stock returns at various horizons $(k)$ are calculated as

$$
\pi_{t, k}=\frac{C P I_{t}-C P I_{t-k}}{C P I_{t-k}} \times 100 \%
$$

and

$$
R_{t, k}=\frac{S I_{t}-S I_{t-k}}{S I_{t-k}} \times 100 \%
$$

As in Boudoukh and Richardson (1993), we report the ordinary least squares (OLS) and instrumental variables (IV) regression results for $k=12$ (one year) and $k=60$ (five years). For each regression, we report the Newey and West (1987) standard errors to take into account of the serial correlation, and possible heteroskedasticity, in residuals due to the use of overlapping data. 


\section{Results}

\subsection{Contemporaneous (OLS) regressions}

Table 1 reports the results of the one-year horizon $(k=12)$ OLS regressions. The results are disappointing but expected. Out of the fifteen cases, only four countries have positive slope estimates. Among these positive estimates, none of them differs significantly from zero at $5 \%$ level. In contrast, six out of the eleven negative slope estimates differ significantly from zero at $5 \%$ level. In ten cases (including six G7 countries), the Fisher Hypothesis (the null of $\beta=1$ ) is rejected at $5 \%$ level. The model fits poorly for most countries. All fifteen countries have an $R^{2}$ less than 0.12 .

Table 2 reports the results of the five-year horizon $(k=60)$ OLS regressions. The results improve somewhat over the short-horizon regression (Table 1). Six countries have positive slope estimates. Only one of them are significantly different from zero at $5 \%$ level. Six out of the nine negative slope estimates are significantly different from zero at $5 \%$ level. In ten cases (including six G7 countries), the Fisher Hypothesis (the null of $\beta=1$ ) is rejected at $5 \%$ level. Based on $R^{2}$, the model fits slightly better using long-horizon data than short-horizon data for all countries except for France and Japan.

Thus, comparing the short-horizon (Table 1) and the long-horizon results (Table 2), longhorizon OLS regressions do not seem particularly promising. This finding differs from Boudoukh and Richardson (1993), who reported more positive and closer-to-one slope estimates from a fiveyear horizon OLS regression of the United States and the United Kingdom. However, we are not surprised to find that the Fisher Hypothesis is rejected for most countries when the model is estimated by OLS because an OLS regression of equation (2) has been shown to yield inconsistent estimate of $\beta$. Thus, investment in stock is not a hedge against contemporaneous inflation.

\subsection{Instrumental variables regressions}

In this section, we consider an IV estimation of the model. As explained earlier, an IV estimator of $\beta$ will be consistent. Following Boudoukh and Richardson (1993), we use lagged inflation rate $\left(\pi_{t-13,12}\right.$ and $\pi_{t-61,60}$ for one-year and five-year horizons respectively) as an instrument for the 
right-hand-side variable (contemporaneous inflation rate). Tables 3 reports the one-year horizon results. As a whole the results are similar to that of a one-year horizon OLS regression. Only four slope estimates are positive, none of them significantly different from zero at $5 \%$ level, as in the short-horizon OLS regression. Eleven estimates are negative, with two of them significantly different from zero at $5 \%$ level. The null of Fisher Hypothesis is rejected at $5 \%$ level only in five cases; and only two of them are members of G7. This is a substantial improvement over the OLS estimation method which is known to be inconsistent in testing the hypothesis. Furthermore, the model fits poorly. None of the country has an $R^{2}$ higher than $0.134 .^{1}$

Table 4 reports the five-year horizon results. The results are encouraging. Out of fifteen cases, eleven countries have positive slope estimates — six of them are significantly different from zero at $5 \%$ level. All negative slope estimates are insignificantly different from zero at 5\% level. The null of Fisher Hypothesis is rejected at 5\% level only in three cases (including Italy, a G7 country), a moderate improvement over the one-year horizon IV result and a substantial improvement over the five-year horizon OLS results. $R^{2}$ also improve substantially, the highest being 0.732 (Italy).

Comparing the results from G7 and Asian countries, we see slightly more support of Fisher Hypothesis, and a positive relation between stock returns and inflation, using long-horizon data from G7 countries than Asian countries. Thus, investment in stock may be used as a hedge against expected inflation.

\section{Concluding remarks}

In short, our results support that at long horizon the nominal returns are positively related to expected inflation but not with contemporaneous inflation. We also find more support of Fisher Hypothesis when the model is estimated by instrumental variables estimation method using longhorizon data than by OLS using short-horizon data. Our findings complement and strengthen those of Boudoukh and Richardson (1993). Future theoretical studies might want to explain why Fisher Hypothesis is rejected when short-horizon data is used but not when long-horizon data is used.

\footnotetext{
${ }^{1}$ The computation of $R^{2}$ for our IV regressions is based on Pesaran and Smith (1994).
} 
One disturbing finding, though, is the negative estimates of the constant term $(\alpha)$ for some countries. If real stock returns is contant, the constant term may be interpreted as the real stock returns under the Fisher Hypothesis. Our finding might suggest that the real stock returns may in fact be time-varying. In our agenda we plan to investigate, statistically, whether real stock returns implied from the Fisher Hypothesis are time-varying.

\section{References}

Bodie, Z.,1976. Common Stocks as a Hedge against Inflation, Journal of Finance 31, 459-470.

Boudoukh, J. and M. Richardson, 1993. Stock Returns and Inflation: A Long-Horizon Perspective, American Economic Review 83, 1346-1355.

Campbell, J., A. Lo and C. MacKinlay, 1997. The Econometrics of Financial Markets. (Princeton University Press).

Fama, E., 1975. Short-term interest rates as predictors of inflation, American Economic Review 65, 269-282.

Fama, E. and G. Schwert, 1977. Asset returns and inflation, Journal of Financial Economics 5, $115-146$.

Nelson, C., 1976. Inflation and Rates of Return on Common Stocks, Journal of Finance 31, 471-83.

Newey, W. and K. West, 1987. A Simple Positive Semi-Definite, Heteroskedasticity and Autocorrelation Consistent Covariance Matrix, Econometrica 55, 703-708.

Pesaran, M. and R. Smith, 1994. A Generalized $R^{2}$ Criterion for Regression Models Estimated by the Instrumental Variables Method, Econometrica 62, 705-710. 
Table 1: Short-horizon (One Year) OLS regression of stock returns on inflation rate

\begin{tabular}{|c|c|c|c|c|}
\hline Country & $\begin{array}{c}\text { Sample period } \\
\text { (\# observations) }\end{array}$ & $\begin{array}{c}\hat{\alpha} \\
\text { (std. error) }\end{array}$ & $\begin{array}{c}\hat{\beta} \\
\text { (std. error) }\end{array}$ & R-square \\
\hline Canada & $\begin{array}{c}1958: 1 \text { to } 1999: 3 \\
(495)\end{array}$ & $\begin{array}{c}9.421 \\
(2.786)\end{array}$ & $\begin{array}{c}-0.385^{* *} \\
(0.649)\end{array}$ & 0.006 \\
\hline France & $\begin{array}{c}1958: 1 \text { to } 1999: 4 \\
(496)\end{array}$ & $\begin{array}{l}14.889 \\
(4.024)\end{array}$ & $\begin{array}{c}-0.919 * * \\
(0.594)\end{array}$ & 0.027 \\
\hline Germany & $\begin{array}{c}1966: 1 \text { to } 1999: 3 \\
(399)\end{array}$ & $\begin{array}{l}20.948 \\
(5.546)\end{array}$ & $\begin{array}{c}-3.475^{* *} \\
(1.222)\end{array}$ & 0.101 \\
\hline Italy & $\begin{array}{c}1958: 1 \text { to } 1998: 12 \\
(492)\end{array}$ & $\begin{array}{l}11.708 \\
(6.701)\end{array}$ & $\begin{array}{c}0.148 \\
(0.905)\end{array}$ & 0.001 \\
\hline Japan & $\begin{array}{c}1958: 1 \text { to } 1999: 3 \\
(495)\end{array}$ & $\begin{array}{l}13.316 \\
(3.404)\end{array}$ & $\begin{array}{c}-0.741^{* *} \\
(0.414)\end{array}$ & 0.022 \\
\hline United Kingdom & $\begin{array}{c}1965: 12 \text { to } 1999: 3 \\
\text { (400) }\end{array}$ & $\begin{array}{l}11.792 \\
(5.037)\end{array}$ & $\begin{array}{c}0.127 \\
(0.802)\end{array}$ & 0.001 \\
\hline United States & $\begin{array}{c}1958: 1 \text { to } 1999: 4 \\
(496)\end{array}$ & $\begin{array}{l}16.584 \\
(2.791)\end{array}$ & $\begin{array}{c}-1.656^{* *} \\
(0.606)\end{array}$ & 0.114 \\
\hline Hong Kong & $\begin{array}{c}1970: 1 \text { to } 1999: 4 \\
(352)\end{array}$ & $\begin{array}{l}22.462 \\
(9.912)\end{array}$ & $\begin{array}{c}0.157 \\
(1.354)\end{array}$ & 0.000 \\
\hline Indonesia & $\begin{array}{c}1984: 4 \text { to } 1998: 12 \\
\text { (177) }\end{array}$ & $\begin{array}{c}34.158 \\
(12.064)\end{array}$ & $\begin{array}{c}-1.080^{* *} \\
(0.273)\end{array}$ & 0.056 \\
\hline Korea & $\begin{array}{c}1976: 1 \text { to } 1999: 3 \\
(279)\end{array}$ & $\begin{array}{l}19.284 \\
(7.058)\end{array}$ & $\begin{array}{c}-0.854^{* *} \\
(0.434)\end{array}$ & 0.032 \\
\hline Malaysia & $\begin{array}{c}1981: 2 \text { to } 1999: 2 \\
(217)\end{array}$ & $\begin{array}{c}0.914 \\
(11.343)\end{array}$ & $\begin{array}{c}2.167 \\
(2.882)\end{array}$ & 0.018 \\
\hline Philippines & $\begin{array}{c}1987: 2 \text { to } 1999: 4 \\
(147)\end{array}$ & $\begin{array}{c}76.982 \\
(41.301)\end{array}$ & $\begin{array}{l}-4.730 \\
(3.390)\end{array}$ & 0.068 \\
\hline Singapore & $\begin{array}{c}1974: 2 \text { to } 1999: 2 \\
(301)\end{array}$ & $\begin{array}{l}10.948 \\
(4.107)\end{array}$ & $\begin{array}{c}-1.390^{* *} \\
(0.673)\end{array}$ & 0.053 \\
\hline Taiwan & $\begin{array}{c}1972: 2 \text { to } 1998: 11 \\
(322)\end{array}$ & $\begin{array}{l}30.503 \\
(8.277)\end{array}$ & $\begin{array}{c}-0.574^{* *} \\
(0.649)\end{array}$ & 0.010 \\
\hline Thailand & $\begin{array}{c}1976: 5 \text { to } 1999: 4 \\
(276)\end{array}$ & $\begin{array}{l}26.140 \\
(7.590)\end{array}$ & $\begin{array}{c}-2.242^{* *} \\
(0.866)\end{array}$ & 0.050 \\
\hline
\end{tabular}

Notes:

1. The results are based on the OLS regression of $R_{t, k}=\alpha+\beta \pi_{t, k}+u_{t, k}$, where $R_{t, k}$ and $\pi_{t, k}$ are respectively the nominal stock returns and inflation rate from time $t-k$ to $t$. Here $k=12$.

2. "**" denotes a rejection of Fisher Hypothesis at $5 \%$ level. 
Table 2: Long-horizon (five-year) OLS regression of stock returns on inflation rate

\begin{tabular}{|c|c|c|c|c|}
\hline Country & $\begin{array}{c}\text { Sample period } \\
\text { (\# observations) }\end{array}$ & $\begin{array}{c}\hat{\alpha} \\
\text { (std. error) }\end{array}$ & $\begin{array}{c}\hat{\beta} \\
\text { (std. error) } \\
\end{array}$ & $\mathrm{R}$-square \\
\hline Canada & $\begin{array}{c}1962: 1 \text { to } 1999: 3 \\
(447)\end{array}$ & $\begin{array}{l}34.639 \\
(7.247)\end{array}$ & $\begin{array}{l}0.211^{* *} \\
(0.281)\end{array}$ & 0.011 \\
\hline France & $\begin{array}{c}1962: 1 \text { to } 1999: 4 \\
(448)\end{array}$ & $\begin{array}{c}50.339 \\
(13.385)\end{array}$ & $\begin{array}{c}-0.004^{* *} \\
(0.264)\end{array}$ & 0.000 \\
\hline Germany & $\begin{array}{c}1970: 1 \text { to } 1999: 3 \\
(351)\end{array}$ & $\begin{array}{l}128.615 \\
(18.076)\end{array}$ & $\begin{array}{c}-4.303^{* *} \\
(0.708)\end{array}$ & 0.371 \\
\hline Italy & $\begin{array}{c}1962: 1 \text { to } 1998: 12 \\
(444)\end{array}$ & $\begin{array}{c}13.440 \\
(17.283)\end{array}$ & $\begin{array}{c}1.006 \\
(0.370)\end{array}$ & 0.121 \\
\hline Japan & $\begin{array}{c}1962: 1 \text { to } 1999: 3 \\
(447)\end{array}$ & $\begin{array}{c}66.192 \\
(18.572)\end{array}$ & $\begin{array}{c}-0.005^{* *} \\
(0.410)\end{array}$ & 0.000 \\
\hline United Kingdom & $\begin{array}{c}1969: 12 \text { to } 1999: 3 \\
(352)\end{array}$ & $\begin{array}{c}90.391 \\
(13.266)\end{array}$ & $\begin{array}{c}-0.363^{* *} \\
(0.260)\end{array}$ & 0.040 \\
\hline United States & $\begin{array}{c}1962: 1 \text { to } 1999: 4 \\
(448)\end{array}$ & $\begin{array}{l}76.303 \\
(8.833)\end{array}$ & $\begin{array}{c}-1.090^{* *} \\
(0.254)\end{array}$ & 0.165 \\
\hline Hong Kong & $\begin{array}{c}1974: 1 \text { to } 1999: 4 \\
(304)\end{array}$ & $\begin{array}{c}79.625 \\
(41.982)\end{array}$ & $\begin{array}{c}0.898 \\
(0.798)\end{array}$ & 0.017 \\
\hline Indonesia & $\begin{array}{c}1988: 4 \text { to } 1998: 12 \\
(129)\end{array}$ & $\begin{array}{l}402.127 \\
(79.896)\end{array}$ & $\begin{array}{c}-3.609 * * \\
(0.984)\end{array}$ & 0.138 \\
\hline Korea & $\begin{array}{c}1980: 1 \text { to } 1999: 3 \\
(231)\end{array}$ & $\begin{array}{l}211.942 \\
(51.758)\end{array}$ & $\begin{array}{c}-1.868^{* *} \\
(0.516)\end{array}$ & 0.152 \\
\hline Malaysia & $\begin{array}{c}1985: 2 \text { to } 1999: 2 \\
(169)\end{array}$ & $\begin{array}{c}27.349 \\
(26.515)\end{array}$ & $\begin{array}{c}1.841 \\
(1.498)\end{array}$ & 0.025 \\
\hline Philippines & $\begin{array}{l}1991: 2 \text { to } 1999: 4 \\
\text { (99) }\end{array}$ & $\begin{array}{c}-3.415 \\
(83.539)\end{array}$ & $\begin{array}{c}2.561 \\
(1.347)\end{array}$ & 0.082 \\
\hline Singapore & $\begin{array}{c}1978: 2 \text { to } 1999: 2 \\
(253)\end{array}$ & $\begin{array}{c}29.065 \\
(15.195)\end{array}$ & $\begin{array}{c}1.308 \\
(0.961)\end{array}$ & 0.055 \\
\hline Taiwan & $\begin{array}{c}1976: 2 \text { to } 1998: 11 \\
(274)\end{array}$ & $\begin{array}{l}321.090 \\
(76.148)\end{array}$ & $\begin{array}{c}-4.032^{* *} \\
(1.285)\end{array}$ & 0.143 \\
\hline Thailand & $\begin{array}{c}1980: 5 \text { to } 1999: 4 \\
(228)\end{array}$ & $\begin{array}{l}239.654 \\
(44.060)\end{array}$ & $\begin{array}{c}-3.872^{* *} \\
(0.807)\end{array}$ & 0.203 \\
\hline
\end{tabular}

Notes:

1. The results are based on the OLS regression of $R_{t, k}=\alpha+\beta \pi_{t, k}+u_{t, k}$, where $R_{t, k}$ and $\pi_{t, k}$ are respectively the nominal stock returns and inflation rate from time $t-k$ to $t$. Here $k=60$.

2. “**" denotes a rejection of Fisher Hypothesis at $5 \%$ level. 
Table 3: Short-horizon (one-year) IV regression of stock returns on inflation rate

\begin{tabular}{|c|c|c|c|c|}
\hline Country & $\begin{array}{c}\text { Sample period } \\
\text { (\# observations) }\end{array}$ & $\begin{array}{c}\hat{\alpha} \\
\text { (std. error) }\end{array}$ & $\begin{array}{c}\hat{\beta} \\
\text { (std. error) }\end{array}$ & R-square \\
\hline Canada & $\begin{array}{c}1959: 1 \text { to } 1999: 3 \\
(483)\end{array}$ & $\begin{array}{c}8.329 \\
(3.470)\end{array}$ & $\begin{array}{l}-0.077 \\
(0.883)\end{array}$ & 0.000 \\
\hline France & $\begin{array}{c}1959: 1 \text { to } 1999: 4 \\
(484)\end{array}$ & $\begin{array}{c}8.116 \\
(4.445)\end{array}$ & $\begin{array}{c}0.366 \\
(0.746)\end{array}$ & 0.003 \\
\hline Germany & $\begin{array}{c}1966: 1 \text { to } 1999: 3 \\
(399)\end{array}$ & $\begin{array}{l}17.135 \\
(7.211)\end{array}$ & $\begin{array}{l}-2.316 \\
(1.841)\end{array}$ & 0.022 \\
\hline Italy & $\begin{array}{c}1959: 1 \text { to } 1998: 12 \\
(480)\end{array}$ & $\begin{array}{c}9.874 \\
(7.761)\end{array}$ & $\begin{array}{c}0.421 \\
(1.081)\end{array}$ & 0.003 \\
\hline Japan & $\begin{array}{c}1959: 1 \text { to } 1999: 3 \\
(483)\end{array}$ & $\begin{array}{l}14.094 \\
(4.087)\end{array}$ & $\begin{array}{c}-0.868^{* *} \\
(0.533)\end{array}$ & 0.013 \\
\hline United Kingdom & $\begin{array}{c}1965: 12 \text { to } 1999: 3 \\
(400)\end{array}$ & $\begin{array}{c}8.853 \\
(4.992)\end{array}$ & $\begin{array}{c}0.514 \\
(0.677)\end{array}$ & 0.008 \\
\hline United States & $\begin{array}{c}1959: 1 \text { to } 1999: 4 \\
(484)\end{array}$ & $\begin{array}{l}11.004 \\
(3.070)\end{array}$ & $\begin{array}{c}-0.360 * * \\
(0.655)\end{array}$ & 0.003 \\
\hline Hong Kong & $\begin{array}{c}1971: 1 \text { to } 1999: 4 \\
(340)\end{array}$ & $\begin{array}{c}88.537 \\
(52.290)\end{array}$ & $\begin{array}{l}-8.117 \\
(6.476)\end{array}$ & 0.059 \\
\hline Indonesia & $\begin{array}{c}1984: 4 \text { to } 1998: 12 \\
\text { (177) }\end{array}$ & $\begin{array}{c}6.992 \\
(39.664)\end{array}$ & $\begin{array}{c}1.329 \\
(3.556)\end{array}$ & 0.002 \\
\hline Korea & $\begin{array}{c}1976: 1 \text { to } 1999: 3 \\
(279)\end{array}$ & $\begin{array}{c}19.857 \\
(10.385)\end{array}$ & $\begin{array}{c}-0.920^{* *} \\
(0.826)\end{array}$ & 0.018 \\
\hline Malaysia & $\begin{array}{c}1981: 2 \text { to } 1999: 2 \\
(217)\end{array}$ & $\begin{array}{c}16.639 \\
(19.099)\end{array}$ & $\begin{array}{l}-2.158 \\
(4.943)\end{array}$ & 0.006 \\
\hline Philippines & $\begin{array}{c}1987: 2 \text { to } 1999: 4 \\
(147)\end{array}$ & $\begin{array}{c}204.258 \\
(109.239)\end{array}$ & $\begin{array}{l}-18.050 \\
(11.125)\end{array}$ & 0.134 \\
\hline Singapore & $\begin{array}{c}1974: 2 \text { to } 1999: 2 \\
(301)\end{array}$ & $\begin{array}{l}18.712 \\
(6.329)\end{array}$ & $\begin{array}{c}-3.810^{* *} \\
(1.536)\end{array}$ & 0.076 \\
\hline Taiwan & $\begin{array}{c}1972: 2 \text { to } 1998: 11 \\
(322)\end{array}$ & $\begin{array}{c}88.662 \\
(43.945)\end{array}$ & $\begin{array}{r}-10.032 \\
(6.123)\end{array}$ & 0.059 \\
\hline Thailand & $\begin{array}{c}1976: 5 \text { to } 1999: 4 \\
(276)\end{array}$ & $\begin{array}{c}48.547 \\
(14.422)\end{array}$ & $\begin{array}{c}-6.016^{* *} \\
(1.906)\end{array}$ & 0.095 \\
\hline
\end{tabular}

Notes:

1. The results are based on the IV regression (with $\left(1, \pi_{t-61,60}\right)$ as instruments) of $R_{t, k}=\alpha+\beta \pi_{t, k}+u_{t, k}$, where $R_{t, k}$ and $\pi_{t, k}$ are respectively the nominal stock returns and inflation rate from time $t-k$ to $t$. Here $k=12$.

2. "**" denotes a rejection of Fisher Hypothesis at $5 \%$ level. 
Table 4: Long-horizon (five-year) IV regression of stock returns on inflation rate

\begin{tabular}{|c|c|c|c|c|}
\hline Country & $\begin{array}{c}\text { Sample period } \\
\text { (\# observations) }\end{array}$ & $\begin{array}{c}\hat{\alpha} \\
\text { (std. error) }\end{array}$ & $\begin{array}{c}\hat{\beta} \\
\text { (std. error) }\end{array}$ & R-square \\
\hline Canada & $\begin{array}{c}1967: 1 \text { to } 1999: 3 \\
(387)\end{array}$ & $\begin{array}{l}-36.734 \\
(27.033)\end{array}$ & $\begin{array}{c}2.501 \\
(0.824)\end{array}$ & 0.250 \\
\hline France & $\begin{array}{c}1967: 1 \text { to } 1999: 4 \\
(388)\end{array}$ & $\begin{array}{l}-116.721 \\
(63.772)\end{array}$ & $\begin{array}{c}4.739 \\
(1.920)\end{array}$ & 0.448 \\
\hline Germany & $\begin{array}{c}1970: 1 \text { to } 1999: 3 \\
(351)\end{array}$ & $\begin{array}{c}-434.422 \\
(3278.876)\end{array}$ & $\begin{array}{c}25.550 \\
(174.091)\end{array}$ & 0.005 \\
\hline Italy & $\begin{array}{c}1967: 1 \text { to } 1998: 12 \\
(384)\end{array}$ & $\begin{array}{l}-278.141 \\
(105.727)\end{array}$ & $\begin{array}{l}6.135^{* *} \\
(1.714)\end{array}$ & 0.723 \\
\hline Japan & $\begin{array}{c}1967: 1 \text { to } 1999: 3 \\
(387)\end{array}$ & $\begin{array}{c}29.378 \\
(29.900)\end{array}$ & $\begin{array}{c}1.445 \\
(0.808)\end{array}$ & 0.021 \\
\hline United Kingdom & $\begin{array}{c}1969: 12 \text { to } 1999: 3 \\
(352)\end{array}$ & $\begin{array}{l}-133.080 \\
(99.059)\end{array}$ & $\begin{array}{c}4.080 \\
(1.875)\end{array}$ & 0.353 \\
\hline United States & $\begin{array}{c}1967: 1 \text { to } 1999: 4 \\
(388)\end{array}$ & $\begin{array}{l}-46.850 \\
(52.536)\end{array}$ & $\begin{array}{c}3.254 \\
(1.880)\end{array}$ & 0.141 \\
\hline Hong Kong & $\begin{array}{c}1979: 1 \text { to } 1999: 4 \\
(244)\end{array}$ & $\begin{array}{l}145.233 \\
(47.103)\end{array}$ & $\begin{array}{l}-0.056 \\
(0.912)\end{array}$ & 0.000 \\
\hline Indonesia & $\begin{array}{c}1988: 4 \text { to } 1998: 12 \\
\text { (129) }\end{array}$ & $\begin{array}{c}607.082 \\
(365.671)\end{array}$ & $\begin{array}{l}-7.421 \\
(6.658)\end{array}$ & 0.036 \\
\hline Korea & $\begin{array}{c}1980: 1 \text { to } 1999: 3 \\
(231)\end{array}$ & $\begin{array}{c}63.944 \\
(83.075)\end{array}$ & $\begin{array}{c}0.968 \\
(1.644)\end{array}$ & 0.005 \\
\hline Malaysia & $\begin{array}{c}1985: 2 \text { to } 1999: 2 \\
(169)\end{array}$ & $\begin{array}{r}-136.616 \\
(49.412)\end{array}$ & $\begin{array}{c}11.580^{* *} \\
(2.625)\end{array}$ & 0.469 \\
\hline Philippines & $\begin{array}{l}1991: 2 \text { to } 1999: 4 \\
\text { (99) }\end{array}$ & $\begin{array}{l}-60.826 \\
(308.202)\end{array}$ & $\begin{array}{c}3.476 \\
(5.134)\end{array}$ & 0.027 \\
\hline Singapore & $\begin{array}{c}1978: 2 \text { to } 1999: 2 \\
(253)\end{array}$ & $\begin{array}{l}-45.007 \\
(35.871)\end{array}$ & $\begin{array}{l}6.103^{* *} \\
(2.191)\end{array}$ & 0.107 \\
\hline Taiwan & $\begin{array}{c}1976: 2 \text { to } 1998: 11 \\
(274)\end{array}$ & $\begin{array}{c}215.297 \\
(169.762)\end{array}$ & $\begin{array}{l}-0.840 \\
(4.838)\end{array}$ & 0.000 \\
\hline Thailand & $\begin{array}{l}1980: 5 \text { to } 1999: 4 \\
\text { (228) }\end{array}$ & $\begin{array}{c}418.995 \\
(181.158)\end{array}$ & $\begin{array}{l}-9.290 \\
(5.663)\end{array}$ & 0.088 \\
\hline
\end{tabular}

Notes:

1. The results are based on the IV regression (with $\left(1, \pi_{t-61,60}\right)$ as instruments) of $R_{t, k}=\alpha+\beta \pi_{t, k}+u_{t, k}$, where $R_{t, k}$ and $\pi_{t, k}$ are respectively the nominal stock returns and inflation rate from time $t-k$ to $t$. Here $k=60$.

2. "**" denotes a rejection of Fisher Hypothesis at $5 \%$ level. 




